Karolina Zioło-Pużuk ${ }^{1}$

Uniwersytet Kardynała Stefana Wyszyńskiego w Warszawie

DOI: https://doi.org/10.26881/jsr.2021.16.14

\title{
NAUCZANIE JEZYKA POLSKIEGO \\ JAKO OBCEGO WŚRÓD OSÓB DUCHOWNYCH - \\ WYZWANIA I ROZWIĄZANIA. \\ STUDIUM PRZYPADKU
}

\section{Wprowadzenie}

Na Wydziale Nauk Humanistycznych Uniwersytetu Kardynała Stefana Wyszyńskiego (UKSW) w Warszawie powstaje podręcznik Szczęść Boże. Skrypt do nauczania języka polskiego jako obcego na poziomie Al dla osób duchownych, będący odpowiedzią na rosnące potrzeby związane z rozwojem współpracy naukowej uczelni z krajami Afryki². Publikacja ta, w formie bezpłatnego e-booka, zostanie udostępniona na stronie Wydawnictwa Naukowego UKSW w 2. połowie 2021 r. Na pełny kurs języka polskiego jako obcego na poziomie A1 składać się będą dwie części skryptu (pierwsza część publikacji została wydana w 2021 r.).

Zanim przystąpiono do pracy nad podręcznikiem na poziomie A1, rozpoczęto - po zakończeniu dwóch semestrów lektoratów z grupą początkującą - proces pogłębionego badania potrzeb szkoleniowych w zakresie nauczania języka polskiego jako obcego i przygotowania do stworzenia podręcznika odpowiadającego na potrzeby stypendystów programu prowadzonego na Wydziale Teologicznym UKSW. Niniejszy artykuł prezentuje założenia związane z badaniem i analizą potrzeb szkoleniowych w procesie planowania nauczania języków obcych i stara się pokazać zakres pojęcia potrzeby szkoleniowe w odniesieniu do nauczania języków; w skład tego terminu wchodzą bowiem zarówno potrzeby językowe, jak i elementy dotyczące procesu uczenia się i nauczania. W artykule przedstawiono wyniki badania opisujące potrzeby i oczekiwania kursantów oraz

${ }^{1}$ k.ziolo-puzuk@uksw.edu.pl, https://orcid.org/0000-0002-6906-6310

${ }^{2}$ Księża biorący udział w zajęciach oraz w opisywanym badaniu potrzeb szkoleniowych i językowych byli uczestnikami programu Organizacja studiów anglojęzycznych dla studentów mniejszości religijnych i etnicznych, pochodzacych z terenów objętych dyskryminacją oraz przemoca, a w szczególności z Afryki prowadzonego na Wydziale Teologicznym UKSW. 
pokazano, jak wpłynęły one na rozwiązania zastosowane w skrypcie Szczęść Boże i program nauczania.

\section{Potrzeby szkoleniowe w nauczaniu języków obcych - podstawowe zagadnienia}

Potrzeby w wymiarze edukacyjnym są wielowymiarowe, wieloaspektowe i zmienne. Potrzeby szkoleniowe to cele „dotyczące możliwych do modyfikowania rozbieżności między stanem obecnym a pożądanym" (Neczaj-Świderska 2005). Jak wspomniano wyżej, w zakresie nauczania języka obcego składają się z potrzeb językowych, stanowiących „rozdźwięk między tym, co aktualnie istnieje, a czymś pożądanym, idealnym" (Gajewska i Sowa 2014: 117), oraz z potrzeb dotyczących środowiska uczenia się (w tym: metod, planowania procesu uczenia się i wyznaczania celów). Należy zwrócić uwagę, że cele, tożsame według tych definicji z potrzebami, muszą być definiowane zgodnie z założeniami SMART, według których realizowalność pozostaje integralnym elementem tego, do czego dążymy. W przypadku nauki języków ważne jest również opisanie celów w czasie oraz ustalenie wspólnie z uczniem (i ewentualnie instytucją zlecającą kurs), które z tych celów (potrzeb) są SMART, tj. konkretne (ang. specific), mierzalne (ang. measurable), osiągalne (ang. achievable), istotne (ang. relevant) i możliwe do określenia w czasie (ang. time-bound) - czyli które z nich staną się elementami programu nauczania.

Louis Porcher (1983: 16) zauważa, że potrzeba to „wszystkie informacje, niezależnie od ich rodzaju, formy, źródła, które są niezbędne lub użyteczne do tego, aby zaplanować proces nauczania, w którego centrum znajduje się uczeń". Z kolei James Dean Brown (2016: 13) jako synonim potrzeb w kontekście ich badania w nauczaniu języków wymienia m.in.: pragnienia, braki, oczekiwania, motywacje, zapotrzebowanie, prośby, niezbędne umiejętności oraz następny krok (x) i x+1 (tj. kolejny krok, który uczeń musi wykonać).

Można więc podsumować, że potrzeba jest takim brakiem, który wymusza działania, narzuca dążenie do celu. Stan następujący po wyeliminowaniu braku opisywany jest jako idealny, pożądany, czyli pozwalający na osiągnięcie efektywności w wykonywaniu danej czynności, a w przypadku nauczania języka w komunikacji na poziomie i w zakresie pożądanym przez uczącego się. Dodatkowo potrzeba musi być opisana zgodnie z akronimem SMART i uwzględniać punkt widzenia wszystkich zaangażowanych, przy czym uczący się pozostaje w centrum budowanego programu nauczania. Dlatego właśnie Elżbieta Gajewska i Magdalena Sowa wskazują, że konieczne jest postrzeganie różnych poziomów potrzeb: indywidualnych, społecznych lub instytucjonalnych, przewidywalnych, nieprzewidywalnych, konkretnych, wyobrażeniowych, wyrażonych, niewyrażonych 
(Gajewska i Sowa 2014: 118). Mając na uwadze przedstawione powyżej definicje oraz rozważania, przeprowadzona analiza potrzeb obejmowała: ankietę online (którą wypełniło 16 księży spośród 25 biorących udział w programie stypendialnym), wywiady (przepytano 4 księży oraz 1 organizatora programu stypendialnego), językową analizę ilościową wybranych tekstów związanych z pracą księży, analizę obserwacji i uwag lektorów (w tym autorki niniejszego artykułu) pracujących przez 4 semestry z grupą księży oraz dziennik fotograficzny jednego z księży (uczestnik programu doktoranckiego, uczący się języka polskiego samodzielnie). W badaniu potrzeb szkoleniowych zastosowano triangulację technik badawczych oraz źródeł informacji, dzięki czemu udało się uzyskać pełniejsze dane. Dodatkowym ważnym elementem zapewnienia wiarygodności otrzymanych wyników był fakt, że analiza potrzeb powstała z uwzględnieniem tzw. metod mieszanych (ang. mixed method research) i łączyła techniki ilościowe z jakościowymi.

\section{Opis sytuacji wyjściowej}

Zajęcia językowe $\mathrm{z}$ grupą księży stanowiły połączenie nauczania języka ogólnego z elementami języka specjalistycznego, przy czym należy podkreślić, że potrzeba włączenia elementów języka specjalistycznego została wyrażona przez uczących się w 3. miesiącu zajęć. Na początku kurs planowany był jako kurs języka ogólnego z dużym komponentem kulturowym; zapotrzebowanie takie otrzymali prowadzący od organizatorów i na podstawie tych założeń został opracowany pierwszy program nauczania. Wprowadzone zmiany, uwzględniające kształtujące się potrzeby instytucji organizującej kurs oraz uczących się, a później poszerzone badanie potrzeb szkoleniowych zapobiegły zjawisku znanemu na gruncie nauczania języka anielskiego jako TENOR (ang. teaching English for no obvious reason) lub ENOP (ang. English with no obvious purpose) (Brown 2016: 5).

Podczas prowadzonych zajęć i rozmów ze studentami oraz na podstawie doświadczeń i refleksji lektorów okazało się, że malejąca frekwencja na zajęciach była związana $\mathrm{z}$ brakiem czasu na powtarzanie materiału, a co za tym idzie z rosnącym poczuciem „odstawania” od grupy. Obawom tym, typowym dla dorosłych uczących się języka, towarzyszyły również trudności związane z faktem, że grupa nie była homogeniczna pod względem poziomu znajomości języka. Dodatkowym czynnikiem demotywującym były niewielkie potrzeby w zakresie komunikowania się w języku polskim - studia doktoranckie odbywały się w języku angielskim, który był również używany przeważnie w rozmowach w miejscu zamieszkania. Uwzględniając te czynniki, zdecydowano się podczas badania i analizy potrzeb zwrócić większą uwagę na środowisko uczenia się 
i poszerzyć badanie potrzeb, o czym wspomniano wyżej, o te z zakresu sposobów uczenia się oraz możliwości uwzględnienia nauki języka w planie tygodnia.

\section{Procedura badania i analizy potrzeb szkoleniowych}

Jak podkreśla Tadeusz Pilch (1998: 147), „Ankieta daje wiedzę obszerną, lecz nie pogłębioną, informuje, nie wyjaśnia", dlatego konieczne było poszerzenie badania potrzeb o inne techniki badawcze. Uzupełnienie wyników ankiety wywiadami pozwoliło na uzyskanie pełniejszego obrazu, czego nie dało się osiągnąć za pomocą pytań zamkniętych czy półotwartych. Zalecenie, że język ankiety powinien być zrozumiały, prosty i pozbawiony żargonu, jest w przypadku ankiety dotyczącej nauczania języka obcego przeprowadzanej wśród uczniów całkowicie niewystarczające. Decyzja o wyborze języka ankiety ma wpływ na otrzymane wyniki. Jak podkreślają Weronika Wilczyńska i Anna Michońska-Stadnik (2010: 169), użycie języka obcego może mieć wpływ również na obszerność i jakość wypowiedzi ankietowanych. Osoby biorące udział w analizowanej ankiecie pochodziły z różnych krajów Afryki, ich znajomość języka polskiego była zaś podstawowa lub zerowa. Metryczka na początku anonimowej ankiety pokazała, że 16 ankietowanych uczyło się języka poniżej 1 roku (najczęściej nie więcej niż 2 godz. dydaktyczne w tygodniu), a jedna osoba uczyła się języka polskiego od 1,5 roku. W przypadku badanej grupy zdecydowano się więc na opracowanie ankiety i przeprowadzenie wywiadów w języku angielskim, który to był językiem edukacji dla badanej grupy. Aby zapewnić jak najpełniejsze zrozumienie intencji badacza, pytania ankiety były konsultowane w wersji angielskiej i polskiej z księdzem Polakiem znającym biegle język angielski.

Ankieta została podzielona na sześć sekcji. Sekcja pierwsza przedstawiała cel badania oraz informowała o zachowaniu anonimowości ankietowanych. Pytania sekcji drugiej dotyczyły czasu, od jakiego odpowiadający uczy się języka polskiego oraz jego pobytu w Polsce. Pytanie trzecie, zamknięte, brzmiało: Czy chciałabyś używać języka polskiego, wykonując obowiąki księdza? Twierdząco odpowiedziało 11 osób $(68,8 \%)$, może - pięć osób $(31,3 \%)$, nikt nie udzielił odpowiedzi negatywnej. Potwierdziło to przypuszczenia wynikające z rozmów z uczestnikami kursu, że możliwość sprawowania posługi duchownego w języku polskim jest dla uczestników programu ważna - a jak pokazały wywiady, pozostaje istotnym czynnikiem wpływającym na pozytywne postrzeganie pobytu w Polsce - ale nie tylko, gdyż zgodnie z deklaracjami uczestników wywiadu, wiąże się ona z elementami wzbogacania duchowości. Podczas wywiadów jeden z rozmówców podkreślił, że praca w parafii byłaby formą dzielenia się swoją wiedzą oraz doświadczeniem. 
Pytania w kolejnych sekcjach, nr 3-5, były układane od ogólnych do szczegółowych i miały charakter zamknięty. W sekcji trzeciej oraz czwartej ankietowani poproszeni byli o określenie stopnia chęci wykonywania danej czynności zawodowej przy korzystaniu z języka polskiego w ogóle (sekcja nr 3) oraz do końca 2021 r. (sekcja nr 4). Pytania z rangowaniem z tych sekcji pozwalały na udzielenie odpowiedzi według skali wyrażającej ważność - od 1 (nieważne) do 5 (bardzo ważne). Pytania dotyczyły pracy duchownego oraz relacji z kolegami (w pracy, na uczelni) i wiernymi. Pytania sekcji czwartej powstały na podstawie opracowanych przez ALTE (The Association of Language Testers in Europe) twierdzeń rozpoczynających się od Can do..., służących do samooceny uczących się języka obcego. Odpowiednio zaadaptowane do specyfiki pracy osoby duchownej twierdzenia pochodziły z obszaru Praca $^{3}$. Sekcja piąta, w której pytania dotyczyły procesu uczenia się oraz przekonań dotyczących czasu potrzebnego do osiągnięcia celu, składała się z pytań zamkniętych pozwalających na wybór tylko jednej odpowiedzi.

Według klasyfikacji Ilony Przybyłowskiej (1978: 63) wywiad przeprowadzony w ramach opisywanego badania to wywiad swobodny, mało ustrukturalizowany (mało ukierunkowany), bez listy pytań, ale z listą zagadnień powstałych na podstawie wyników ankiety, podczas wywiadu zaś zadawano pytania otwarte, zachęcające do dłuższych wypowiedzi, zindywidualizowane ze względu na respondenta i pozostające z związku z udzielanymi odpowiedziami, otwarte na ich kontekst. Wywiad przeprowadzono w formie wideorozmowy za pomocą aplikacji Google Meets (w jednym wypadku odbyto rozmowę telefoniczną). Przeprowadzono trzy rozmowy indywidulane oraz jeden wywiad z dwoma uczestnikami. Średnio każde ze spotkań trwało 60 min. Celem wywiadów było doprecyzowanie i pogłębienie wyników otrzymanych w ankiecie.

\section{Wyniki ankiety (sekcja nr 5) oraz wywiadu}

W sekcji piątej zadano ankietowanym pięć pytań. Na każde z nich udzielono 16 odpowiedzi:

1. Sadzę, że aby osiagnać swoje cele, POWINIENEM brać udziat w zajęciach...

- 2 godz. tygodniowo - 7 osób $(43,8 \%)$

- 4 godz. tygodniowo - 5 osób $(31,3 \%)$

- 6 godz. tygodniowo - 2 osoby $(12,3 \%)$

- 8 godz. tygodniowo - 1 osoba $(6,3 \%)$

- więcej- 1 osoba $(6,3 \%)$

${ }^{3}$ https://www.cambridgeenglish.org/Images/28906-alte-can-do-document.pdf [dostęp: 20.07.2021]. 
2. Aby osiągnąć swoje cele, JESTEM GOTÓW brać udział w zajęciach...

- 2 godz. tygodniowo - 7 osób (43,7\%)

- 4 godz. tygodniowo - 7 osób (43,7\%)

- 6 godz. tygodniowo - 0 osób

- 8 godz. tygodniowo - 1 osoba $(6,3 \%)$

- więcej-1 osoba (6,3\%)

3. Aby osiągnąć swoje cele, POWINIENEM uczyć się poza zajęciami językowymi (samodzielnie)...

- 2 godz. tygodniowo - 6 osób (37,5\%)

- 4 godz. tygodniowo - 4 osoby $(25 \%)$

- 6 godz. tygodniowo - 2 osoby $(12,5 \%)$

- 8 godz. tygodniowo -1 osoba $(6,2 \%)$

- więcej-3 osoby $(18,8 \%)$

4. Aby osiągnąć swoje cele, JESTEM GOTÓW uczyć się poza zajęciami językowymi (samodzielnie)...

- 2 godz. tygodniowo - 6 osób (37,5\%)

- 4 godz. tygodniowo - 5 osób (31,3\%)

- 6 godz. tygodniowo - 2 osoby $(12,5 \%)$

- 8 godz. tygodniowo - 2 osoby $(12,5 \%)$

- więcej- 1 osoba $(6,2 \%)$

5. Czy chciałbyś brać udział w dodatkowych zajęciach online?

- tak-14 osób (87,5\%)

- nie-0 osób

- może - 2 osoby $(12,5 \%)$

Kursanci w większości uważają zaangażowanie podczas zajęć na poziomie 2-4 godz. dydaktycznych za optymalne. Potwierdziła to również obserwacja frekwencji: w pierwszym roku zajęć zaplanowano 8 godz. dydaktycznych tygodniowo, ale uczniowie zwracali uwagę, że liczba ta jest nie do pogodzenia z innymi zobowiązaniami na uczelni, dlatego frekwencja spadała, a nierówności w opanowaniu materiału między uczniami rosły. W kolejnym roku akademickim zajęcia odbywały się w wymiarze 4 godz. tygodniowo, dzięki czemu udało się utrzymać zaangażowanie każdego ze studentów na podobnym poziomie. W pytaniu o dodatkowe (pozalekcyjne) zaangażowanie przeważały odpowiedzi wskazujące, że powinno ono wynosić 2-4 godz. Brak rozbieżności między zdaniami opisującymi stan pożądany a tymi dotyczącymi możliwości zaangażowania się w naukę pozwala przypuszczać, że uczący się mają realistyczne podejście do nauki. Może mieć ono źródło w fakcie, że badania grupa to osoby znające nie mniej niż dwa języki obce i potrafiące w sposób precyzyjny opisać zarówno swoje oczekiwania, jak i możliwość ich osiągnięcia w czasie. Wywiady jednak pokazały, że wniosek taki jest nie do końca prawdziwy. W osobistych rozmowach wybrzmiało, iż studenci 
chcą podczas zajęć otrzymywać podstawowe informacje, schematy gramatyczne, które - według nich -mogą się stać podstawą do samodzielnego pogłębiania wiedzy i zdobywania umiejętności, ćwiczenia użycia języka w sytuacjach życia codziennego. Studenci pośrednio wyrażali potrzebę wsparcia w stosowaniu technik uczenia się w ramach pracy własnej. Dodatkowo podkreślali potrzebę nauki języka przed przyjazdem do Polski, np. w formie kursów online, dzięki czemu nie czuliby się zagubieni. Zainteresowanie nauką online (w tym zajęciami prowadzonymi asynchronicznie, ćwiczeniami powtórzeniowymi online) zauważalne była również w odpowiedziach na pytania ankiety.

Podczas wywiadów księża wskazywali, że - obok poznania podstaw gramatyki - najważniejsze są dla nich poprawna wymowa i umiejętność prawidłowego odczytania zapisanych wyrazów, nawet jeśli szczegółowe znaczenie poszczególnych wyrazów nie jest dla nich jasne. Uważali oni, że dzięki tej umiejętności mogliby brać udział we wspólnej modlitwie z wiernymi, w spotkaniach parafian, w odprawianiu mszy po polsku, i podkreślali, że nie chcieliby z powodu niedoskonałej, niewyraźnej wymowy wywoływać efektu komicznego lub wpływać negatywnie na pełne uczestnictwo osób słuchających.

\section{Podsumowanie}

Przedstawiony wyżej fragment badania potrzeb szkoleniowych opisywanej grupy prowadzi do następujących wniosków:

- kursanci zauważają, że możliwość używania języka polskiego w codziennej komunikacji, a przede wszystkim w pracy oraz na uczelni, jest dla nich istotnym elementem motywującym do dalszej nauki;

- brak możliwości używania języka polskiego oraz bycia częścią wspólnoty wierzących ,po polsku” powoduje, że czują się oni izolowani, pozostawieni na marginesie;

- respondenci deklarują brak czasu na naukę - zarówno samodzielną, między zajęciami, jak i zorganizowaną w formie lektoratów;

- rozwiązaniem powyższego problemu, według studentów, jest włączenie elementów e-learningu asynchronicznego jako stałego elementu kursu;

- studenci wskazali prawidłową wymowę jako ważny element kształcenia oraz jeden z elementów włączenia się do społeczności i brania udziału w mszy po polsku jako osoba duchowna (poprzez np. prawidłowe odczytanie fragmentów Pisma Świętego);

- jak można wnioskować z wypowiedzi podczas wywiadów, studenci potrzebują wsparcia w zakresie metod pracy nad językiem oraz wspierania autonomii rozumianej jako praca nad skuteczną samodzielną nauką, wyznaczenie celów i poszukiwanie metod ich realizacji. 
W odpowiedzi na potrzebę pracy nad technikami uczenia się oraz wyznaczania celów do programu kursu wprowadzono zadanie projektowe polegające na prowadzeniu przez studenta fotodziennika ${ }^{4}$. Celem projektu jest zachęcenie uczących się do refleksji nad potrzebami językowymi i szkoleniowymi przez fotografowanie (telefonem) przedmiotów, których nazw nie znają, a chcieliby je poznać, oraz symbolicznego przedstawiania sytuacji, w których czuli się zagubieni z powodu braków językowych albo - przeciwnie - dumni z tego, jak sobie poradzili. Ćwiczenie to wzmacnia autonomię w wyznaczaniu celów oraz pogłębia refleksję nad potrzebami szkoleniowym w zakresie języka obcego. Zdjęcia mogą później służyć jako fotofiszki i być również inspiracją dla nauczyciela; ponadto mogą stać się elementem zajęć, których celem jest stworzenie mapy marzeń i mapy celów językowych oraz edukacyjnych (Zioło-Pużuk 2019). Podczas zajęć planowanych w kolejnych latach lektorzy będą również prezentować techniki mnemoniczne i zachęcać studentów, aby dzielili się swoimi pomysłami na skuteczną naukę. Kursantom zostanie też zaproponowana możliwość zapisania się do grupowego newslettera wysyłanego 2, 3 razy w tygodniu (częstotliwość ustalą kursanci), który będzie zawierał ćwiczenia, krótkie nagranie do odsłuchania lub tekst z pytaniami. Wykonanie zadania z newslettera nie będzie wymagać więcej niż 5-10 min samodzielnej pracy. Taka forma aktywności między zajęciami pozwoli na wprowadzenie regularności w pracy nad językiem w nieobciążającej formie oraz będzie odpowiedzią na potrzebę pracy z nowymi technologiami. W pierwszej części skryptu ta potrzeba została zrealizowana przez korzystanie z kodów QR odsyłających do ćwiczeń na platformie LearningApps do pracy samodzielnej lub podczas zajęć.

Tematyka poszczególnych rozdziałów skryptu odpowiada na zapotrzebowanie uczestników związane z używaniem języka polskiego podczas pracy duchownego. Tytuły rozdziałów to: Szczęść Boże!, Jak ma pan na imię?, Co u księdza stychać?, To jest mój kościót i moja parafia, Ile kosztuje chleb?, W kancelarii parafialnej, Pobłogosław, Panie Boże, nas i te dary, Jestem młodym księdzem, O 12 w niedziele odprawiam mszę, Dziś świeci stońce, jutro będzie padać deszcz, Rok liturgiczny. Dodatkowo w podręczniku zamieszczono autentyczne dokumenty używane w kancelarii parafialnej, które stanowią podstawę ćwiczeń komunikacyjnych i pozwalają na przygotowanie się z do ewentualnej pomocy w kancelarii. Wykorzystanie autentycznych dokumentów podnosi również motywację do nauki i wspiera przekonanie, że język polski może być narzędziem wykorzystywanym do komunikacji w realnych sytuacjach dotyczących pełnienia posługi duchownego.

${ }^{4}$ Przeprowadzono pilotaż z jednym uczestnikiem w tej grupie oraz jako działanie prowadzone przez jeden semestr $\mathrm{z}$ inną grupą studentów. 
Każdy rozdział otwiera krótki słowniczek tematyczny, co jest pomocą dla uczących się, gdyż pozwala na łatwiejsze powtarzanie leksyki oraz budowanie skojarzeń poprzez tematyczne jej grupowanie. Podobną funkcję pełni również polsko-angielski słowniczek 96 podstawowych terminów religijnych zamieszczony na końcu publikacji. W założeniu autorki słowniczki mają spowodować, że skrypt będzie prawdziwie podręczną pomocą w nauce języka polskiego, szansą na szybkie podstawowe przygotowanie się do sytuacji komunikacyjnej, która może nastąpić. Zgodnie z zapotrzebowaniem uczących się skrypt nie mógł jednak przybrać formuły zbliżonej do rozmówek, gdyż w wywiadach kursanci podkreślali, że pogłębione poznawanie zasad gramatyki jest dla nich ważne, daje podstawę do samodzielnej nauki. Podczas zajęć studenci prosili o ćwiczenia oparte na drylach językowych, ale jednocześnie sami chcieli odkrywać i opisywać zasady gramatyczne. Tam gdzie było to możliwe, wprowadzono więc elementy świadomej indukcji, tzn. metody prezentacji gramatyki będącej ,„[...] sterowanym odkrywaniem (ang. conscious induction as guided discovery), kiedy to uczący się - na bazie przykładów specjalnie dobranych przez nauczyciela - samodzielnie formułują regułę gramatyczną" (W. Decco; cyt za: Knyś 2017: 36) W drugiej części skryptu (będącej jeszcze w opracowaniu) zostaną zaproponowane ćwiczenia realizujące założenia indukcyjnego nauczania gramatyki.

Jednoznaczna potrzeba doskonalenia prawidłowej wymowy znalazła odzwierciedlenie w pierwszym rozdziale książki, prezentującym podstawy polskiej wymowy, oraz w zamieszczeniu w każdym z rozdziałów modlitwy lub modlitw, które pozwalają na nauczenie się prawidłowego ich brzmienia oraz skojarzenia wyrazu z zapisem.

Choć otrzymane wyniki, zgodnie z założeniami badania potrzeb szkoleniowych, nie powinny być generalizowane, to jednak mogą służyć jako inspiracja i podstawa do stawiania hipotez badawczych. Główna z nich dotyczy faktu, że nauczanie języka ogólnego w grupach dorosłych może szybko prowadzić do zniechęcenia i poczucia braku celu. Dlatego też kursy językowe dla dorosłych, w tym duchownych, muszą nie tylko zawierać elementy wiedzy o danym kraju i jego kulturze, ale również dawać narzędzia do komunikacji w pracy i sytuacjach formalnych. W przypadku opisywanych grup niedostateczna znajomość języka polskiego postrzegana była jako uciążliwość, swego rodzaju zubożenie w obszarze duchowości. Dostrzeżenie tej ważnej, ale nie oczywistej potrzeby było możliwe dzięki przeprowadzeniu pogłębionej analizy potrzeb szkoleniowych, które to działanie powinno poprzedzać planowanie każdego kursu języka obcego dla dorosłych. 


\section{Bibliografia}

Brown J.D. (2016), Introducing Needs Analysis and English for Specific Purposes, Routledge, London.

Gajewska E., Sowa M. (2014), LSP, FOS, Fachsprache... Dydaktyka języków specjalistycznych, Werset, Lublin.

Knyś M. (2017), O zaletach, trudnościach i potrzebie indukcyjnego nauczania gramatyki języka polskiego jako obcego, „Języki Obce w Szkole” nr 1.

Neczaj-Świderska R. (2005), Rozpoznanie i analiza potrzeb szkoleniowych organizacji, „E-mentor” nr 8.

Pilch T. (1998), Zasady badań pedagogicznych, Wydawnictwo Akademickie Żak, Warszawa.

Porcher L. (1983), Migrant workers learning French in France: a practical experiment, w: Case studies in identifying language needs, red. R. Richterich, Pergamon Press, Council of Europe.

Przybyłowska I. (1978), Wywiad swobodny ze standaryzowana lista poszukiwanych informacji i możliwość jego zastosowania w badaniach socjologicznych, „Przegląd Socjologiczny” nr 30.

Wilczyńska W., Michońska-Stadnik A. (2010), Metodologia badań w glottodydaktyce. Wprowadzenie, Avalon, Kraków.

Zioło-Pużuk K. (2019), Kształtowanie autonomii i umiejętności samooceny uczniów na lekcjach języka obcego - wykorzystanie mapy marzeń, „Języki Obce w Szkole" nr 2.

\section{Streszczenie}

\section{Nauczanie języka polskiego jako obcego wśród osób duchownych - wyzwania i rozwiązania. Studium przypadku}

Artykuł prezentuje wyniki badań dotyczących potrzeb szkoleniowych w zakresie nauczania języka polskiego jako obcego prowadzonych w grupie księży doktorantów z krajów Afryki studiujących na Wydziale Teologicznym UKSW w Warszawie. Przeprowadzone badanie potrzeb stało się podstawą do zaprojektowania skryptu do nauki języka polskiego jako obcego dla osób duchownych zatytułowanego Szczęść Boże!, którego pierwsza część ukazała się w 2021 r. Artykuł przedstawia, jak otrzymane wyniki badania potrzeb wpłynęły na konstrukcję podręcznika oraz programu nauczania.

Słowa kluczowe: język polski jako obcy, język polski jako obcy dla osób duchownych, potrzeby szkoleniowe, nauczanie języka specjalistycznego 


\section{Summary \\ Teaching Polish as a Foreign Language to Clergymen - Challenges and Solutions. A Case Study}

The article presents the results of the learning needs analysis concerning teaching and learning Polish as a foreign language conducted among a group of priests - PhD students from African countries studying at the Faculty of Theology at the Cardinal Stefan Wyszyński University in Warsaw. Presented research became the basis for designing a script for teaching Polish as a foreign language for clergy entitled God Bless You!, the first part of which was published in 2021. The article presents how the results of the needs analysis influenced the structure of the textbook and the curriculum.

Keywords: Polish as a foreign language, teaching Polish as a foreign language to clergymen, learning needs, LSP (language for specific purposes) 